\title{
Activity of Zinc in Fused Ternary Alloy \\ (Zn-Al-Mg System)
}

\section{Zensaku Kozuka*, Jyoichiro Moriy ama* and Isao Kushima*}

The authors already reported the vapor pressure of $\mathrm{Zn}$ measured with several molten binary alloys ${ }^{1), 2)}$. In this paper the vapor pressure of zinc in $\mathrm{Zn}-\mathrm{Al}-\mathrm{Mg}$ ternary alloy melt at $720^{\circ} \mathrm{C}$ is reported, and a few the rmodynamic properties of this melt are treated. Experimental method and apparatus were the same as those reported in the previous papers ${ }^{1), 2}$.

The vapor pressure of zinc was determined at twelve different compositions of the molten alloy as shown in Fig. 1, the numerical values in which show the activity of zinc.

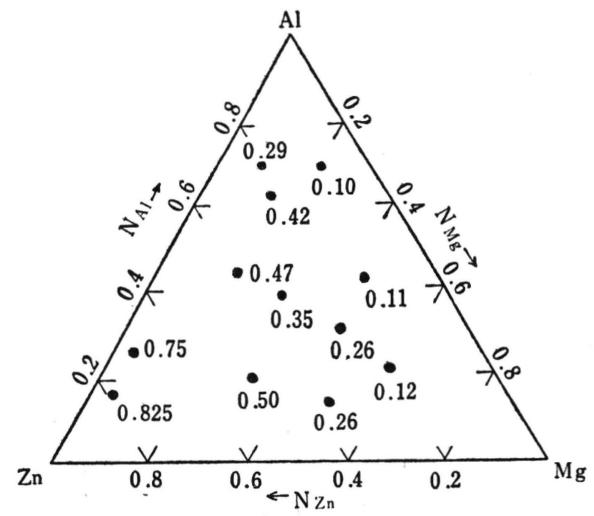

Fig. 1 Activity of Zinc in $\mathrm{Zn}-\mathrm{Al}-\mathrm{Mg}$ ternary alloy melt at $720^{\circ} \mathrm{C}$

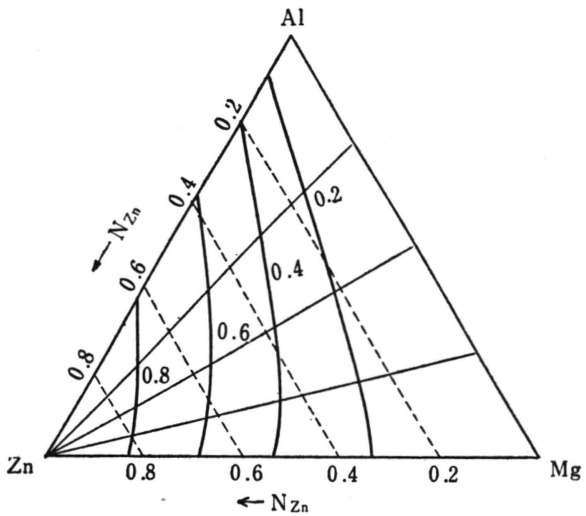

Fig. 2 Isoactivity lines of Zinc in $\mathrm{Zn}-\mathrm{Al}-\mathrm{Mg}$ melt at $720^{\circ} \mathrm{C}$

Based on these experimental results, the iso-activity curves are obtained and shown in Fig. 2. The excess free energy, $F^{x s}$, of this metallic melt can be obtained by means of the equations both derived by Darken $^{3}$.

$$
\begin{aligned}
& F^{x s}=\left(1-N_{\mathrm{Zn}}\right)\left[\int_{1}^{N_{\mathrm{Zn}}} \frac{\bar{F}_{\mathrm{Zn}}^{x s}}{\left(1-N_{\left.\mathrm{Zn}_{\mathrm{n}}\right)^{2}}\right.} d N_{\mathrm{Zn}}\right]_{N_{\mathrm{Al}} / N_{\mathrm{Mg}}}+N_{\mathrm{Al}}\left[\bar{F}_{\mathrm{Al}}^{x s}\right]_{N_{\mathrm{Zn}}=1}+N_{\mathrm{Mg}}\left[\bar{F}_{\mathrm{Mg}}^{x s}\right]_{N_{\mathrm{Z}}=1} \\
& F^{x s}=\left(1-N_{\mathrm{Zn}}\right)\left[\int_{0}^{N_{2 \mathrm{n}}} \frac{\bar{F}_{\mathrm{Zn}}}{\left(1-N_{\left.\mathrm{Zn}_{\mathrm{n}}\right)^{2}}\right.} d N_{\mathrm{Zn}}+F_{\text {binary Al-Mg }}^{x s}\right]_{N_{\mathrm{Al}} / N_{\mathrm{Mg}}}
\end{aligned}
$$

The activities of $\mathrm{Zn}-\mathrm{Al}$ and $\mathrm{Zn}-\mathrm{Mg}$ systems were reported by the present authors, while the activity of $\mathrm{Al}-\mathrm{Mg}$ system was reported by Schneider. From above results, $F^{x s}$ at any compositions can be calculated with equation (1) or alternatively by means of Equation (2).

The iso-excess free energy curves are obtained by calculation with Equation (2) which is more reliable than Euation (1).

From the results shown in Fig. 3 , the $\bar{F}_{i}{ }^{x s}$ at various compositions of the binary and pseudo-binary lines in the ternary system are obtained (Fig. 4). These values are determined by the slope-intercept method or by means of the Gibbs-Duhem equation.

Also the activities of $\mathrm{Al}$ and $\mathrm{Mg}$ are calculated with ease and shown in Fig. 5.

Using the results for $\mathrm{Zn}-\mathrm{Al}$ and $\mathrm{Zn}-\mathrm{Mg}$ binary systems, $F^{x s}$ is calculated with Equation (1), and the $F_{\mathrm{Al}-\mathrm{Mg}}^{x s}$ may be evaluated by the help of the following Equation (3).

* Dept. of Metallurgy, Faculty of Eng., Kyoto Univ., Kyots

The original written in Japanese can be seen in Electrochem. Soc. Japan 28, 691 (1960). 


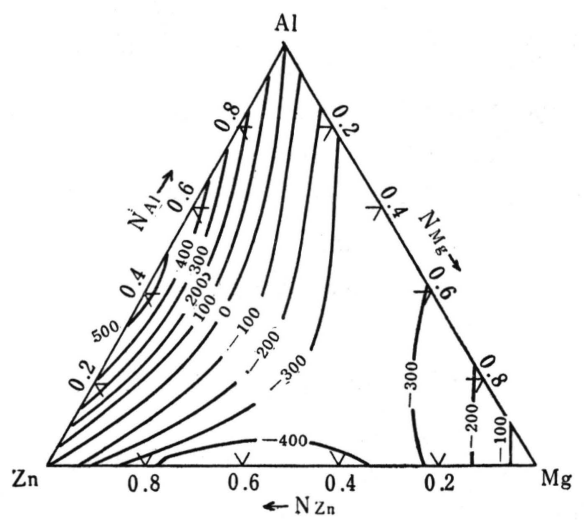

Fig. 3 Excess molal free energy $\left(F^{x s}\right)$ for $\mathrm{Zn}-\mathrm{Al}-\mathrm{Mg}$ at $720^{\circ} \mathrm{C}$ in 100 calorie steps

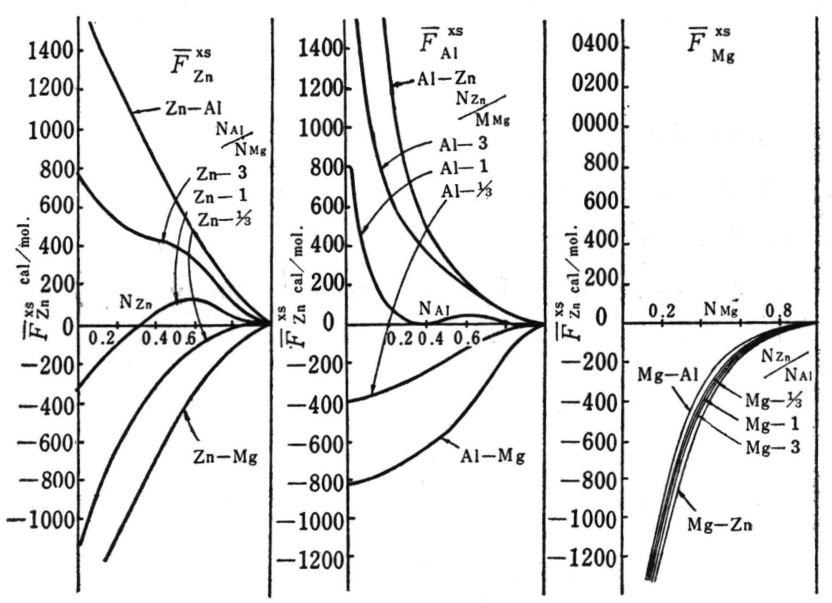

Fig. 4 Excess partial molal free energy $\left(\bar{F}_{i}{ }^{x s}\right)$ for $\mathrm{Zn}-\mathrm{Al}-\mathrm{Mg}$ melt at $720^{\circ} \mathrm{C}$

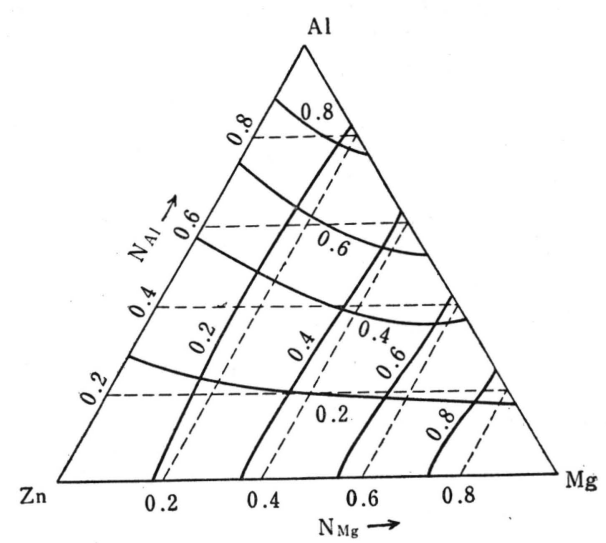

Fig. 5 Isoactivity lines of aluminum and magnesium in $\mathrm{Zn}-\mathrm{Al}-\mathrm{Mg}$ melt at $720^{\circ} \mathrm{C}$ 


$$
F_{\mathrm{Al}-\mathrm{Mg}}^{x s}=-\left[\int_{0}^{1} \frac{\bar{F}_{\mathrm{Zn}}^{x s}}{\left(1-N_{\mathrm{Zn}}\right)^{2}} d N_{\mathrm{Zn}}\right]_{N_{\mathrm{Al}} / N_{\mathrm{Mg}}}+N_{\mathrm{Al} 1}\left[\bar{F}_{\mathrm{Al}}^{x s}\right]_{N_{\mathrm{Zn}}=1}+N_{\mathrm{Mg}}\left[\bar{F}_{\mathrm{Mg}}^{x s}\right]_{N_{\mathrm{Zn}}=1}
$$

The value calculated by the above equation does not agree with the results obtained by Schneider. This discrepancy may be caused by the error in graphic integration and also by the difficulty in accurately evaluating the $\bar{F}_{\mathrm{Zn}}^{x s} /\left(1-N_{\mathrm{Zn}_{\mathrm{n}}}\right)^{2}$ for such a highly concentrated $\mathrm{Zn}$-solution. Finally, the $F^{x s}$ was calculated, referring to an equation recently derived by $\mathrm{Ptak}^{5}$.

In an earlier paper ${ }^{2}$ the present authors have shown the following relations with respect to $\mathrm{Zn}-\mathrm{Al}$ and $\mathrm{Zn}-\mathrm{Mg}$ binary alloy melts.

$$
\begin{aligned}
& \mathrm{Zn}-\mathrm{Al} \text { system }\left\{\begin{array}{l}
\log \gamma_{\mathrm{Zn}}=(480 / T-0.1195)\left(1-N_{\mathrm{Zn}_{\mathrm{n}}}\right)^{1.3} \\
\log r_{\mathrm{Al}}=(480 / T-0.1195)\left[\left(1-N_{\mathrm{Zn}_{\mathrm{n}}}\right)^{1.3}-\frac{1.3}{0.3}\left(1-N_{\mathrm{Zn}_{\mathrm{n}}}\right)^{0.3}+\frac{1}{0.3}\right]
\end{array}\right. \\
& \mathrm{Zn}-\mathrm{Mg} \text { system }\left\{\begin{array}{l}
\log \gamma_{\mathrm{Zn}_{\mathrm{n}}}=(-1019 / T+0.666)\left(1-N_{\mathrm{Zn}_{\mathrm{n}}}\right)^{1.55} \\
\log \gamma_{\mathrm{Mg}}=(-1019 / T+0.666)\left[\left(1-N_{\mathrm{Zn}_{\mathrm{n}}}\right)^{1.55}-\frac{1.55}{0.55}\left(1-N_{\mathrm{Zn}_{\mathrm{n}}}\right)^{0.55}+\frac{1}{0.55}\right]
\end{array}\right.
\end{aligned}
$$

From Schneider's results, the next eguation is obtained with respect to $\mathrm{Al}-\mathrm{Mg}$ system.

$\mathrm{Al}-\mathrm{Mg}$ system $\log \gamma_{\mathrm{Mg}}=(-2280 / T+1.708)\left(1-N_{\mathrm{Mg}}\right)^{3.9}$

$$
\log \gamma_{\mathrm{Al}}=(-2280 / T+1.708)\left[\left(1-N_{\mathrm{Mg}}\right)^{3.9}-\frac{3.9}{2.9}\left(1-N_{\mathrm{Mg}}\right)^{2.9}+\frac{1}{2.9}\right]
$$

From the above six equations, the following equation can be derived.

$$
\begin{aligned}
F^{x s}= & (7320+1.825 T) N_{\mathrm{Al}}\left\{1-\left(1-N_{\mathrm{Zn}}\right)^{0.3}\right\}+(-8460+5.54 T) N_{\mathrm{Mg}}\left\{1-\left(1-N_{\mathrm{Zn}}\right)^{0.55}\right\} \\
& +(-3600+2.70 T) N_{\mathrm{Al}}\left\{1-\left(1-N_{\mathrm{Mg}}\right)^{2.9}\right\}
\end{aligned}
$$

The iso-excess free energy curves are plotted on the basis of the values calculated from the above relations (Fig. 6).

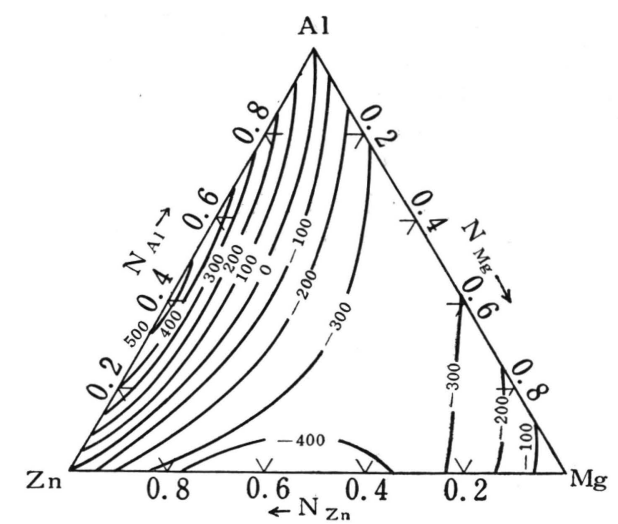

Fig. 6 Calculated excess molal free energy $\left(F^{x s}\right)$ for $\mathrm{Zn}-\mathrm{Al}-\mathrm{Mg}$ melt at $720^{\circ} \mathrm{C}$ in 100 calorie steps

These values agree fairly well with the experimental results in Fig. 3. The following equtions for the heat of mixing and excess entropy, respectively, were also derived.

These calculated values are graphically shown in Fig. 7 and Fig. 8.

$$
\begin{aligned}
\Delta H= & 7320 N_{\mathrm{Al}}\left\{1-\left(1-N_{\mathrm{Zn}}\right)^{0.3}\right\}-8460 N_{\mathrm{Mg}}\left\{1-\left(1-N_{\mathrm{Zn}}\right)^{0.55}\right\} \\
& -3600 N_{\mathrm{Al}}\left\{1-\left(1-N_{\mathrm{Mg}}\right)^{2.9}\right\} \\
S^{x s}= & 1.825 N_{\mathrm{Al} 1}\left\{1-\left(1-N_{\mathrm{Zn}}\right)^{0.3}\right\}-5.54 N_{\mathrm{Mg}}\left\{1-\left(1-N_{\mathrm{Zn}}\right)^{0.55}\right\} \\
& -2.70 N_{\mathrm{Al}}\left\{1-\left(1-N_{\mathrm{Mg}}\right)^{2.9}\right\}
\end{aligned}
$$




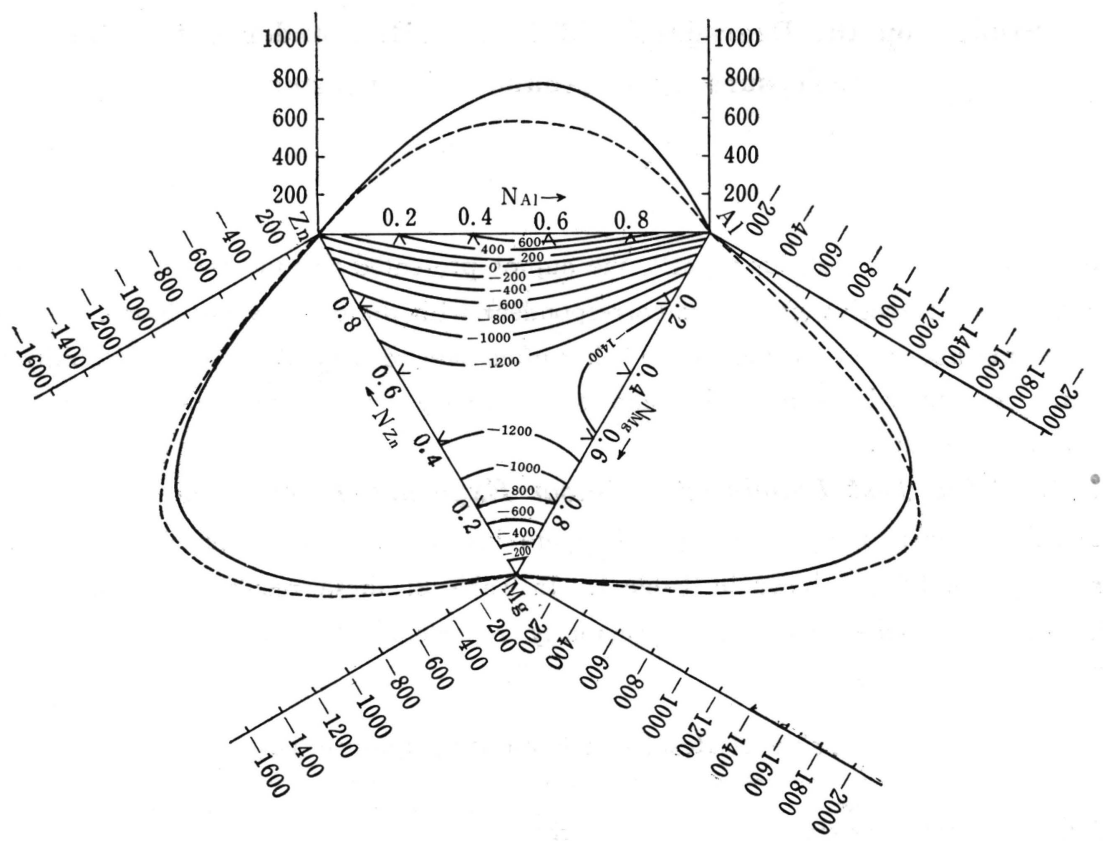

Fig. 7 Calculated heat of mixing $(\Delta H)$ for $\mathrm{Zn}-\mathrm{Al}-\mathrm{Mg}$ melt at $720^{\circ} \mathrm{C}$ in 200 calorie steps

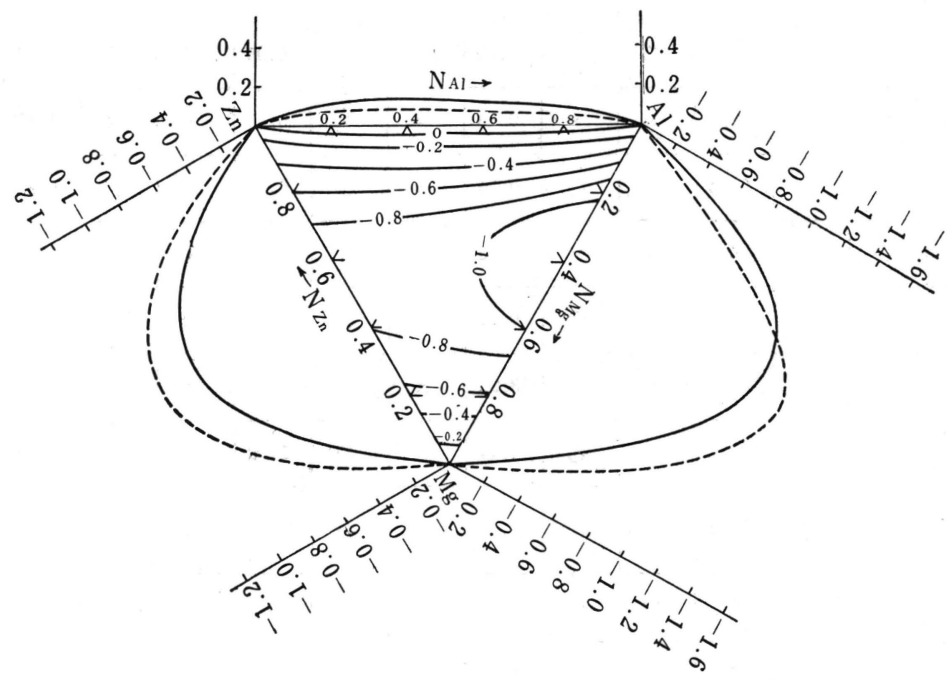

Fig. 8 Calculated excess molal entropy $\left(S^{x s}\right)$ for $\mathrm{Zn}-\mathrm{Al}-\mathrm{Mg}$ melt at $720^{\circ} \mathrm{C}$ in 0.2 calorie steps

(Received May 28, 1960)

\section{Literature :}

1), 2) Z. Kozuka et al., J. Electrochem. Soc. Japam 28, 456 (1960): 28, 523 (1960).

3) L.S. Darken, J. Amer. Chem. Soc. 72, 2909 (1950).

4) A. Schneider, E.K. Stoll, Z. Electrochem. 47, 7519 (1941).

5) W. Ptak, Bergakademie (11-3) 168 (1959). 